10 years ESJ

Special edition

\title{
Judicial Judgments and Non-Privative Measures of Freedom: Legal Criteria and Social Impacts
}

\author{
José Vicente \\ Centre for Research and Studies in Sociology \\ (CIES - ISCTE - IUL - Lisbon, Portugal) \\ and ESECS - Polytechnic Institute of Leiria, Leiria, Portugal \\ Susana Loureiro \\ ESECS - Polytechnic Institute of Leiria, Leiria, Portugal
}

Doi: $10.19044 /$ esj.2021.v17n26p78

Submitted: 08 April 2021

Accepted: 08 June 2021

Published: 09 August 2021
Copyright 2021 Author(s)

Under Creative Commons BY-NC-ND

4.0 OPEN ACCESS

Cite As:

Vicente J. \& Loureiro S. (2021). Judicial Judgments and Non-Privative Measures of Freedom: Legal Criteria and Social Impacts. European Scientific Journal, ESJ, 17 (26), 78. https://doi.org/10.19044/esj.2021.v17n26p78

\section{Abstract}

This paper focuses on the main lines of action that guide the debate between social and legal issues in the attribution of non-custodial penalties. The emphasis is specifically placed on the vulnerability to social exclusion and how to categorize offenders. This begins from the premise that certain stigmatizing attributes and relationships put the person in a position of fragility that conditions them to live their citizenship to the full. It is well known that the social rules and laws instituted at national level exist to condition and establish limits among citizens in order to promote healthy coexistence and non-compliance, which is punishable by law. Infractions are based on the social inadequacy or pathological disability of some citizens. The existence of social control mechanisms is felt by a large part of the community as a means of security and an advantage in guaranteeing the stability and sustainability of the social structure and organization. In this context, the judicial sentences with penalties and non-custodial measures are in force in the legal system with the principle of deterring offenders and reducing the contagion of experiences in the prison context. The judicial penalties, which initially were seen as merely having a compensatory function to the evil of crime, are answered with 
the evil of the penalties. This evolved to the current conception, and the purposes that should guide the application of the penalties are exclusive, preventive, general, and special. This change in perspective happens because the socialization of the agent assumes a preponderant role today in determining the judicial sentence (private or non-custodial sentences) to be applied in order to contribute to its regeneration, re-education, re-socialization or social reintegration. From the data collected, in the latest reports prepared in Portugal by the Directorate-General for Rehabilitation and Prison Services and by the Statistics Services of Justice, it is clearly seen that there has been a concern by judges/magistrates to articulate with these and other community structures to collect social information and social reports. This is done so that the penalties are attributed fairly, in order to take into account the regenerative character and to promote the social and professional reintegration of the offenders.

Keywords: Social exclusion, social reinsertion, social reintegration, social rehabilitation system, judicial sentences, non-custodial penalties, deprived of liberty, social reports

\section{Introduction}

In the elaboration of this paper, the theoretical reflection focuses on humanistic and comprehensive theories. The definition and contextualization of the concepts presented are reinforced from the perspective of social justice and the need to increase the interdependence between the harshness and crudeness of the current laws and the vulnerability of people's individual and collective processes.

The conceptual instruments in social sciences propose an objective interpretation of social reality at the intersection with the explanatory theories of legal systems as a way of verifying the centrality of the person in a rule of law.

This reading brings about a reflection on the problem of social exclusion, stigma, and the need for social control in the light of the social sciences and, in another perspective, the legal sciences, in particular, on the legislation on non-custodial penalties presented in the penal code. The purpose of this is to determine and regulate the acts considered by the legislator as criminal offenses.

For the construction of this paper, the qualitative methodology was used. Documentary analysis made in reports and documents produced annually by the Directorate-General for the Reintegration of Prison Services and on the Justice Statistics website was used for data collection. ${ }^{1}$ Data

${ }^{1}$ https://estatisticas.justica.gov.pt/sites/siej/pt-pt 
analysis was done in an inductive, comprehensive, and interpretative way because this multilevel reading is considered more adequate to the complexity of this social reality.

The first dimension of the analysis is focused on understanding the typology of social reports as well as clinical and psychosocial information`s collected by the judges in order to decide on the application of non-custodial penalties. The second dimension of the analysis is focused on realizing how the interdisciplinary practices are configured, the collaborative work between the judges, and the specialists who prepare the social and clinical reports.

\section{The Legal and Social System: Social Exclusion and Stigma in the Loss of Citizenship}

There is a set of social norms and rules that people have to comply with in their lives. However, not everyone is able to respect this, especially the standards of the normative model of what is "good", " beautiful", "convenient" or "competitive".

Practically, all spheres of modern society seem to be subject to these levels or limits of normality that define, in response, a failure in relation to the norm. This failure in relation to normality seems to be part of the processes of exclusion (Xiberras, 1993, p.29).

Robert Castel (1998) defines social exclusion "as a descending path along which there are successive ruptures in the individual's relationship with society." Above all, a rupture in relation to the labor market translates into unemployment (namely prolonged unemployment) or an irreversible disconnection from that market.

The same author refers to social exclusion as "the process by which certain individuals and groups are systematically hindered from accessing positions that would allow them to have an autonomous way of life within the social norms framed by institutions and values in a given context." (Castel, 1998, p.73)

According to Capucha (1998), exclusion occurs when society does not offer all its members the possibility to participate and enjoy all these rights and feel they are members in the fulfillment of their duties. This happens to the point that the disadvantaged lose their full citizenship and are prohibited from participating in standards of living which are considered acceptable by the society in which they live (Capucha, 1998).

Vulnerability to social exclusion is increasingly asserting itself as a phenomenon that is present in modern society. In this sense, "the birth in an upper middle-class family, a successful and long school career and a stable professional career, are no longer a guarantee that a situation of exclusion cannot survive" (OEFP, 2001, p.9). 
The society establishes ways of categorizing people, thereby making them create expectations and requiring others to comply with instituted norms. The intention is to stop having originality to consider the other a common creature, thus transforming him into a person who can be diminished, bad, dangerous, and weak.

"The term "stigma" is used in reference to one or more derogatory attributes towards the person. Three distinctly different types of stigma can be mentioned. First, there are the abominations of the body - the various physical deformities. Second, the blame of an individual character perceived as weak will, tyrannical or unnatural passions, false and rigid beliefs, and dishonesty. These being inferred from known reports of, for example, mental disorder, prison, addiction, alcoholism, homosexuality, unemployment, suicide attempts, and radical political behavior. Finally, there are the tribal stigmas of race, nation, and religion which can be transmitted through lineage and equally contaminate all members of a family." (Goffman, 1982, p.7)

Para Stafford and Scott (1986), cited by Cardoso and Siqueira (2011), expose the concept of stigma by giving it more complexity than that proposed by Goffman and other authors of his time, relating it to social control, norms, and deviations. Goffman worked with the idea of normality and deviation. However, Stafford and Scott developed concepts for this term by involving them with the idea of social control, thereby making the understanding of the concept of stigma more complex (Cardoso \& Siqueira, 2011).

Guy Rocher (1976) stated that it encompasses the set of positive and negative sanctions in the concept of social control which claim to be the same. According to him, it includes "the set of positive and negative sanctions that the society uses to ensure compliance of the conducts with established models". Social control in general is a means of preventing individuals from acting impulsively in accordance with the rules and standards instituted socially in order to maintain the functions of respect and cordiality that are fundamental, basic, and essential in interpersonal relationships, with behavior that keeps group experiences healthy (Rocher,1976).

This critical perspective "about the mechanisms of social control present in modern society stimulated the creation of a set of works aimed at institutions directly involved with the issue of deviation, crime, and criminality - police, criminal justice, prison - as well as for those only indirectly involved with the problem - hospital, nursing home, school, family, etc." (Alvarez, 2004, p.170).

The "Discipline and Punish" study by Michel Foucault had an enormous impact on the analysis of punishment practices and criminal policies, which is "gradually becoming, as already said, an alternative 
approach paradigm in relation to more orthodox conceptions of Liberalism and Marxism. Both forms of punishment were analyzed, in an unprecedented way, as true technologies in action and the relationship of these technologies with the society as a whole proved to be much more complex than in other types of analysis." (Ibidem, 2004, p.172)

The punitive phenomenon resulting from the non-acceptance of individual behaviors that attack the collective sense manifested itself in all periods of the life of human collectivities.

"All the discourse that justifies the adoption of the model that attributes exclusivity to the State to punish is a reflection of ideologies that permeate the different forms of power at a given time and place such as the economic, the political, and the social. (...) Social conflicts have widened and there is the need to regulate them. The impersonality with which the idea of offending the divinity was given allowed the use of the judicial sentence as a means to prevent the expansion of the violence contained in widespread revenge.” (Gomes, 2018, p.37)

In this sense, the principles are changed and new strategies are defined. The criminal now assumes the status of a citizen, and this will be decisive. Any infraction will be considered as being carried out against society in general. Society has the right to defend and punish itself but in a less fierce and smoother way because the citizen who makes the law does not commit crimes against himself (Brites, 2007, p.171).

Nobody ignores the fact that man is a being whose nature is essentially social. This takes place in the cultural world, and its rationality is affirmed here. Therefore, this is manifested in the achievements of life, which takes place in coexistence.

However, coexistence requires the existence of rules, ethical norms, propositions or linguistic statements that express a MUST-BE that guide human interrelationships, discipline the behaviors of each man, and transmit the necessary security to the life of a person in the relationship with others (Justo, 2015).

\section{Purpose of Judicial Sentence Application: From Punishment to Social Reintegration}

The evolution of law and other social orders has accompanied the dominant thinking, as well as behavior and life in society, with regard to legal and criminal rules and final judicial sentences. According to Garcia (2013), it is necessary to realize that the penal system is not an historical legal-social construction. Thus, the political, social, economic, and cultural changes affect its epistemology, its teleology, and its modes of operation (García, 2013, p. 4). 
In this context, the debate is recurrent. This means that it evolved from absolute theories or retribution, according to which the judicial sentence is conceived, as an absolute, metaphysical, and ethical demand of justice. This is regardless of utilitarian considerations and the greater or lesser convenience that may result in the perspective of social interest in a specific concrete historical context.

In terms of retribution, court judgments were seen as a compensatory function. In the current conception, the purposes that should guide the application of judicial sentences (penalties) must be preventive, general, and special. This is because the offender's socialization assumes a preponderant role in determining the sentence to be applied. Nowadays, judicial sentences (penalties), at least in theoretical terms, are not aimed at protecting society from the danger of the agent of crime, but they are focused on the regeneration, reeducation, resocialization, or social reintegration of the individual.

In addition, Leite (2011) stated that "the Portuguese penal system remains committed, at least, in the preparation of the law and in the formal construction of legal institutes, in defending the offender's resocialization and in improving the application of non-custodial penalties."

However, this resocialization is not always achieved. This is because, in practice, there is still a clear preference of the courts in the application of effective prison sentences to the detriment of non-custodial penalties and measures in the community.

According to the Portuguese reality, the prison sentence is not only applied as a final ratio. Escudeiro (2011) further stated that "the goal of executing judicial sentences that prohibit freedom is to socialize the prisoner. Nonetheless, the prison many times, instead of having an educational role, helps the offender to become most disgusted with society." (Escudeiro, 2011)

Concerns in this area are similarly reported in the Ombudsman's ${ }^{2}$ report where one can read: "Overcrowded chains". The environment is sometimes gloomy and humid, and small prison cells with furniture are worn out by continuous use. Food can also be served cold and, in some situations, sparingly provided. This is how our prisons could be described (...) (Neves, 2016, p. 6).

Portuguese prisons are crammed with people. Due to poor economic conditions, they remain there for a long time. There is also a considerable percentage of sentenced people on short prison terms.

This is confirmed by the data provided by the latest Annual Internal Security Report, for the year 2019, regarding the short duration of private sentences. It was revealed that the percentage of prisoners serving sentences

\footnotetext{
2 The Ombudsman is the statutory body whose task is 'to defend and promote the rights, freedoms, guarantees and legitimate interests of citizens.'
} 
of less than six years represent $56 \%$ of the total number of prisoners' serving time in prison in Portugal (RASI, 2019).

This happens in the Portuguese legal system when the right or even the duty on the part of the judicial authorities to obtain knowledge about the person who is the subject of a criminal investigation is enshrined in order to individualize a correct criminal reaction.

In this regard, and prior to the imposition of a penalty in particular, the subjective elements of the crime must be framed. This refers to elements related to the person on whom the criminal investigation falls such as their degree of socialization, characteristics of their personality, their development, professional and academic skills obtained, the conditions and way of life, the habits and dependencies, etc., which are relevant to the determination of the penalty to be applied (Marchuk, 2013).

Therefore, the Penal Code in force stipulates, with regard to the purposes of penalties and security measures, that "the application of penalties and security measures is aimed at protecting legal assets and reintegrating the agent into society. Thus, the penalty cannot exceed the measure of guilt. The security measure can only be applied if it is proportionate to the gravity of the fact and the danger of the agent." 3

For the realization of this aspiration and concretization of the aforementioned subjective elements of the crime, there is, at the disposal of organs of judicial bodies, the technical accessory which is carried out by the Social Reintegration Services. Hence, it elaborates various instruments of technical support. The main purpose is to provide the judicial process with relevant data about the person on whom the criminal investigation falls, which is suitable for the pursuit of reintegrating the person into the social fabric until the intervention of the justice system over the same ends.

In addition, a set of sanctions are enshrined in the Portuguese legal system, which do not deprive liberty and are guided by two common vectors. The first vector involves the stipulation of certain injunctions to defendants or convicts, while the second vector entails monitoring through social reintegration services in order to fulfill obligations, proposals, and psychosocial support.

This nucleus consists of the suspension of the execution of the prison ${ }^{4}$ sentence, the probation for the suspension of the execution of the internment of non-accountable persons, the freedom for evidence, and the provisional suspension of the process ${ }^{5}$.

\footnotetext{
${ }^{3}$ Article 40 of Decree-Law No 48/95 of 15 March, modified by Law No. 58/2020, of 31/08.

${ }^{4}$ Articles 50. ${ }^{\circ}$ a $57 .{ }^{\circ}$ Portuguese Penal Code

${ }^{5}$ Articles $61 .{ }^{\circ}$ a $64 .{ }^{\circ}$ do PPC
} 
There is also another category of sanctions that are characterized by the idea of work in favor of the community or the State. This include Provision of work in favor of the community and Replacement of the fine for working days ${ }^{6}$, whose implementation and the intervention of social reintegration services is of great importance in the re-socialization of the agent ${ }^{7}$.

However, there are legal means but they are not always used properly. If the tone of the issue is in terms of the application or any feeling that prohibits freedom or execution in the community, focusing on the specific needs of the Agent of crime, such as its regeneration, re-education, re-socialization or social reintegration, is necessary to increase its field of application.

\section{Interpretative Data Analysis: The Contributions of the Various Specialists Involved in the Processes}

For these legal mechanisms to be properly implemented, it is neccessary for the Directorate-General for Reinsertion and Prison Services to work together in an interdisciplinary way. This is the department of the Portuguese state and is responsible for criminal prevention, punishment, and social reintegration.

This department is also responsible for the management of the educational and prison guardianship systems and for articulating with all the other structures of the community, including social security and private Social Solidarity Institutions that have contributed significantly to welcome and accompany/support the people with non-custodial sentences.

Nowadays, "non-custodial penalties are an example of how the preservation of human rights can also be guaranteed outside prison, as well as support projects for the prevention and fight against crime, which do not focus on punishment." (Martins, 2010, p.30)

According to the statistics presented by the Ministry of Justice in conjunction with the Directorate-General for Reinsertion and Prison Services, the concern of the Portuguese Courts is clearly seen in trying to understand the social, family, and professional context of the offenders.

Assistance in the context of decision-making can be seen in the presentencing phase:

"It is contextualized in the need for the Courts and the Public Prosecution Office to guarantee procedural means and adequate data for the pursuit of judicial purposes and for the reinsertion of the user in the social fabric, until the intervention of the justice administration system on it ends. This advice is carried out in the collection prior to

\footnotetext{
${ }^{6}$ Article $98 .^{\circ}$ do PPC

${ }^{7}$ https://dgrsp.justica.gov.pt/Justi\%C3\%A7a-de-adultos/Penas-e-medidas-na-comunidade
} 
the decision of a wide range of elements, namely on subjective aspects of the crime. This refers to elements related to the person targeted in criminal proceedings which favor the individualization of the criminal reaction." (DGRSP, 2018, p.34)

In the table below, it is possible to see the increase in requests for information and social reports that have contributed significantly to the decision making of the judges. Particularly, this can be seen when faced with different types of crimes that fit this type of criminal frames.

Total requests for reports and hearings received by document type Year 2019

\begin{tabular}{|l|l|l|l|l|l|l|l|l|}
\hline $\begin{array}{l}\text { Tipo de } \\
\text { documento }\end{array}$ & Total & $\begin{array}{l}\text { Relatórios } \\
\text { sociais }\end{array}$ & $\begin{array}{l}\text { Informações } \\
\text { sociais }\end{array}$ & $\begin{array}{l}\text { Relatórios de } \\
\text { perícia sobre } \\
\text { personalidade }\end{array}$ & Planos & $\begin{array}{l}\text { Apoio } \\
\text { técnico e } \\
\text { audições }\end{array}$ & Outros & $\begin{array}{l}\text { Taxa } \\
\text { Execução }\end{array}$ \\
\hline Recebidos & $\begin{array}{l}57 \\
502\end{array}$ & 28660 & 8144 & 49 & 17536 & 2625 & 488 & \\
\hline Executados & $\begin{array}{l}\mathbf{5 0} \\
\mathbf{9 7 0}\end{array}$ & 25172 & 7847 & 33 & 15246 & 2246 & 426 & 88,58 \\
\hline
\end{tabular}

Table 1. Source : statistics of portuguese justice - Available in https://estatisticas.justica.gov.pt/sites/siej/pt-pt/Paginas/ReinsercaoSocial.aspx

The notes presented in the reading of the table are according to the website statistics of the Portuguese Government.

Therefore, it is possible to analyze that the values refer to all requests for technical advice to support decision-making received by the DGRSP and to all reports and hearings recorded. This is done within the scope of the execution of sentences and measures applied, depending on the type of document. Also, there may be more than one request for advice per person.

I. Social Report: This includes information on the defendant's family and socio-professional insertion and, eventually, the victim which is prepared by social reintegration services, with the aim of assisting the court or judge in knowing the defendant's personality ((art. 1. ${ }^{\circ}$, al. g) e art. $370 .^{\circ} \mathrm{CPPl}$ ).

II. Social Information: This includes response to specific requests regarding the personal, family, school, work or social situation of the accused and, possibly, of the victim which is prepared by the social reintegration services, with the aim of assisting the court or judge in 
knowing the personality of the defendant accused ((art. 1. ${ }^{\circ}$, al.h) e art. $\left.370 .^{\circ} \mathrm{CPP}\right)$.

III. Personality Expert Report: For the purpose of assessing the defendant's personality and dangerousness, there may be an examination of his psychic characteristics, independent of pathological causes, as well as his degree of socialization. The expertise may be relevant, in particular, to the decision on the revocation of pre-trial detention, the fault of the agent, and the determination of the sanction. It should be deferred to specialized services, including social reintegration services, or, when it is not possible or convenient, to specialists in criminology, psychology, sociology or psychiatry (art. $1600^{\circ} \mathrm{CPP}$ ).

IV. Hearings: The Court may request the hearing, without a swearing, of the technicians of social reintegration in order to provide clarifications on the social report prepared.

$V$. Social Reinsertion Plan: This contains the rehabilitation goals to be achieved by the convict, the activities that the convicted person must develop, the respective phasing, and the support and surveillance measures to be adopted by the social reintegration services (art. $54 .^{\circ}$ $C P)$.

In September 2020, a more in-depth analysis was carried out, which was presented in an informative summary. This was prepared at the request of the Subcommittee on Social Reintegration and Prison Affairs. Thus, this is "with the aim of providing its members with sufficient comparative elements in relation to the themes of judicial sentences that deprive a person of his or her freedom in different legal systems."

Consequently, the legal systems of Germany, Canada, Denmark, Spain, France, Italy, Portugal, and the United Kingdom were presented in alphabetical order and sorted out in order to know the possible and noncustodial penalties foreseen in each of them (Ferreira, et al., 2020, p.4).

In this document, it is possible to verify that there is a pre-disposition on the part of the justice of all these countries to reduce the effective prison sentences, while trying to apply non-custodial penalties and decide on their application in the different courts. Therefore, they agreed that the personality of the prisoner should always be assessed such as his training, his conduct in serving his penalty, his family and social situation, the circumstances of the crime committed, and the relevance of the legal assets that may be affected by recidivism of the crime (Ibidem, p.20).

It should also be noted that as of December 14, 1990, the United Nations General Assembly in its resolution 45/110 had adopted the minimum 
rules of the united nations for the elaboration of non-custodial penalties that became known by the "TOKYO RULES ${ }^{8 "}$. In the same document in point 7.1 , it is suggested that, in all cases and whenever the offense so permits, an effort should be made to make an exhaustive survey of the offender's life.

The purpose of this guideline requires obtaining reports and social information so that the judicial authority can use these documents prepared by other specialists or competent and authorized departments for the purpose.

Furthermore, these reports must be factual, objective, impartial, and contain relevant information about the social environment of the offender in order to know the type of infractions that he usually commits and those that are specifically attributed to him.

All of this interdisciplinary and cooperative work has the main purpose of providing relevant information and recommendations for the purposes of determining the judicial sentence.

\section{Conclusion}

After analyzing the current panorama of the use of non-custodial penalties, it appears that these are fundamental to reduce the contagion of experiences, delinquency, and marginality that happens in prisons, as well as the need to reduce the number of prisoners in effective prison.

Consequently, it can be evident that very significant steps have been taken to build collaborative work that links the genesis of social sciences and legal sciences that are based on the respect and protection of individuals as seen in the Universal Declaration of Human Rights.

Only through "the recognition of the inherent dignity of all members of the human family and their equal and inalienable rights, do we find the foundation of freedom and justice." (DUDH, 1948)

All alternative ways to effective imprisonment will certainly be an asset for not letting social inequalities flourish and increasing social disqualification, which in turn will make the society more preventive and less repressive.

The relationships that coexist between the offender's need to understand family, housing, and sociocultural conditions are additional systems that have a pedagogical character.

\footnotetext{
${ }^{8}$ Adopted by the United Nations General Assembly in its resolution 45/110, of December 14, 1990 Minimum rules of the united nations for the elaboration of non-custodial measures (TOKYO RULES), available at https://gddc.ministeriopublico.pt/sites/default/files/regrasdetoquio.pdf

${ }_{9}^{9}$ Universal Declaration of Human Rights. Adopted and proclaimed by the United Nations General Assembly (resolution 217 A III) on December 10, 1948.
} 
The model of deprivation of liberty, whenever possible, should be avoided. This means that this measure already contains a stigma.

After serving their non-custodial penalties, prisoners tend to need assistance in their social and professional reintegration. Therefore, from the data collected in the documents under study, it is observed that non-custodial penalties are simultaneously a faster way of signaling offenders together with the various socio-psychosocial support services.

In this context, information and technical reports prepared by several specialists who work in the courts have been rethought, thereby constituting fundamental instruments for understanding the purpose of the judicial sentence and the offense to be considered in its entirety.

It is not for the social sciences or the legal sciences to resolve all of these issues. However, it is also unreasonable to deny any and all roles in the face of this reality (...) and suffocate the recipient of the penal rule in terms that make the concern for the other a kind of reason for existing. Also, this is present at all times and it sometimes hinders self-realization and prevents one from freely developing his or her personality (Guaragni, 2011).

\section{References:}

1. Alvarez, M.C. (2021). controle social notas em torno de uma noção polêmica. são Paulo em perspetiva, 18(1): 168-176. Obtido em 2 de Mraço de 2021, de https://www.scielo.br/pdf/spp/v18n1/22239.pdf

2. Brites, I. (2007). A centralidade de Vigiar e Punir. História da violência nas prisões, na obra de Michel Foucault (Recensão Crítica). Revista Lusófona de Educação (10), pp. 167-184. Obtido em 7 de 2 de 2021, de https://revistas.ulusofona.pt/index.php/rleducacao/article/view/638/53 3.

3. Capucha, L. (2005). Desafios da Pobreza. Oeiras: Celta

4. Costa, A. (1985). Bruto et al. (orgs.),. A pobreza em Portugal. Lisboa: Fundação Calouste Gulbenkian.

5. DGRSP (2018). Relatório de Atividades e Autoavaliação. DireçãoGeral de Reinserção e Serviços Prisionais - Ministério da Justiça, Direção de Serviços de Organização, Planeamento e Relações Externas. Lisboa: DGRSP-MJ. Obtido em 4 de 2 de 2021, de

6. https://dgrsp.justica.gov.pt/Portals/16/Instrumentos\%20de\%20Planea mento $\% 20 \mathrm{e} \% 20 \mathrm{Gest} \% \mathrm{C} 3 \% \mathrm{~A} 3 \mathrm{o} /$ Relat $\% \mathrm{C} 3 \% \mathrm{~B} 3$ rio $\% 20 \mathrm{de} \% 20$ ativida des/2018/RA_2018.pdf?ver=2019-07-11-154949-080

7. Escudeiro, M. J. (2011). Execução das penas e medidas privativas da liberdade- Análise Evolutiva e Comparativa. (O. d. Advogados, Ed.) Revista da Ordem dos Advogados, Vol.II, pp. 567-622. Obtido em 15 
de 2 de 2021, de https://portal.oa.pt/upl/\%7B16258631-095e-4c50bc13-27981e007a2a\%7D.pdf

8. Ferreira, C., Colaço, L., Godinho, M. J., Amorim, N., Carvalho, P. B., \& Rolo, S. (2020). Penas alternativas à privação de liberdade: Enquadramento nacional e internacional. Assembleia da República , Divisão Informativa de Lesgislativa Parlamentar . Lisboa: Divisão de Informação Legislativa e Parlamentar - DILP. Obtido em 27 de 02 de 2021, de https://ficheiros.parlamento.pt/DILP/Publicacoes/Sinteses/43.PenasA lternativasPrivacaoLiberdade/43.pdf

9. García, J.Á. (2013). A gestão da exclusão social por parte do sistema penal na contemporaneidade: novas epistemologias para uma análise socio-económica do sistema penal,. (P. d. Criminais6substancialmente, Ed.) Revista Liberdades - no 13 , pp. 128. Obtido em 26 de 02 de 2021, de http://plataforma.ibccrim.org.br/publicacoes/redirecionaLeituraPDF/7 355

10. Goffman, E. (1982). Estigma: notas sobre a manipulação da identidade deteriorada. Rio de Janeiro: Zahar.

11. Gomes, G.L. (2018). A legitimidade e adequação das alternativas penais à pena privativa de liberdade: a experiência brasileira. Tese de Doutoramento, Universidade Autónoma de Lisboa, Departamento do Curso de Doutoramento em Direito, Lisboa. Obtido em 22 de 01 de 2021, de

https://repositorio.ual.pt/bitstream/11144/3856/1/Tese\%20Geder\%20 Gomes.pdf

12. Gomes, G.L. (2018). A legitimidade e adequação das alternativas penais à pena privativa de liberdade: a experiência brasileira. Tese de Doutoramento, Universidade Autónoma de Lisboa, Departamento do Curso de Doutoramento em Direito, Lisboa. Obtido em 22 de 01 de 2021, de

https://repositorio.ual.pt/bitstream/11144/3856/1/Tese\%20Geder\%20 Gomes.pdf

13. Guaragni, F.A. (2011). A função do Direito Penal e os "sistemas peritos". Revista JULGAR, p. 15. Obtido em 17 de 2 de 2021, de http://julgar.pt/wpcontent/uploads/2014/07/AFUN\%C3\%87\%C3\%83ODODIREITOPE NALEOSSISTEMASPERITOS.pdf

14. Justo, A.S. (2015). Introdução ao Estudo do Direito ( $7^{\mathrm{a}}$ ed.). Coimbra: Coimbra Editora.

15. Leite, A.L. (2011). Execução da pena privativa de liberdade e ressocialização em Portugal: Linhas de um esboço. Revista de 
Criminologia e Ciências Penitenciárias, I(1), pp. 2-34. Obtido em 02 de 3 de 2021, de https://repositorio-aberto.up.pt/bitstream/10216/56629/2/49790.pdf

16. Martins, A.T. (2010). Serviço Social e Privação de Liberdade.Qual o Papel do Serviço Social nos Estabelecimentos Prisionais Portugueses. Relatório de final de Curso., Instituto Politéncico de Beja-Escola Superior de Educação, CPIHTS - Centro Português de Investigação em História e Trabalho Social, Beja. Obtido em 12 de 2 de 2021, de http://www.cpihts.com/PDF05/Ana\%20Martins.pdf

17. Marchuk, I. (2013). The Fundamental Concept of Crime in International Criminal Law. Library of Congress.London.Springer

18. Neves, M. (2016). O Provedor de Justiça e a realidade prisional. Conferência Internacional As nossas prisões: que presente e que futuro? (pp. 1-7). Lisboa. Obtido em 19 de 2 de 2021, de https://www.provedorjus.pt/site/public/archive/doc/O_Provedor_de_Justica_e_a_realidade_ prisional-MN.pd

19. OIT -Organização Internacional do Trabalho (2003). A luta contra a pobreza e a exclusão social em Portugal. Genebra: Bureau Internacional do trabalho.

20. RASI (2019). Relatório anual de Segurança Interna 2019. Sistema de Segurança Interna, Gabinete do Secretário Geral, Portugal. Obtido em 13 de 2 de 2021, de

https://www.portugal.gov.pt/pt/gc22/comunicacao/documento?i=relat orio-anual-de-seguranca-interna-2019-

21. Siqueira, R. \& Cardoso, H. (2011). O conceito de estigma como processo social: uma aproximação teórica a partir da literatura norteamericana. imagonautas. Revista interdisciplinaria sobre imaginarios sociales. pp. 92-113. Obtido a 4 de março de 2021, de https://dialnet.unirioja.es/descarga/articulo/4781280.pdf

22. Xiberras, M. (1996). As Teorias da Exclusão - Para uma construção do imaginário do desvio. Instituto Piaget. 